\title{
Historical morphological development of the Eastern Scheldt tidal basin (The Netherlands)
}

\author{
M. Eelkema ${ }^{1}$, Z.B. Wang ${ }^{1,2}$ and M.J.F. Stive ${ }^{1}$
}

\begin{abstract}
The Eastern Scheldt tidal basin has changed drastically in the past five centuries under the influence of both human interventions as well as extreme events. In 1530 A.D. a storm-surge inundated large parts in the landward end of the basin, and in the following four centuries local inhabitants reclaimed about as much land as was inundated in that storm. To investigate the effects of these processes on basin morphology, several different simplified geometries of the basin are used in order to gain insight into the evolution of the tidal currents over the centuries. From this model it appears that the large-scale inundations cause the basin to scour to greater depth. This in turn causes the ebb-tidal delta to grow, and causes the disappearance of the tidal watershed between the Eastern Scheldt and the Grevelingen tidal basins. Land reclamations have not been able to turn these trends around.
\end{abstract}

Key words: Tidal basin, Eastern Scheldt, Land reclamation, Inundation, Ebb-tidal delta, Tidal watershed

\section{Introduction}

The Eastern Scheldt (Figure 1) is the original mouth of the Scheldt River but lost its river influence during the $14^{\text {th }}$ and $15^{\text {th }}$ centuries due to the connecting and scouring of the Western Scheldt. The mouth of the Eastern Scheldt obtained its present-day location around 4000 B.P. and has remained in more or less the same location ever since. The tidal basin was flanked on either side by two barrier islands, with intertidal mudflats and salt marshes in the elongated tidal divides behind those islands.

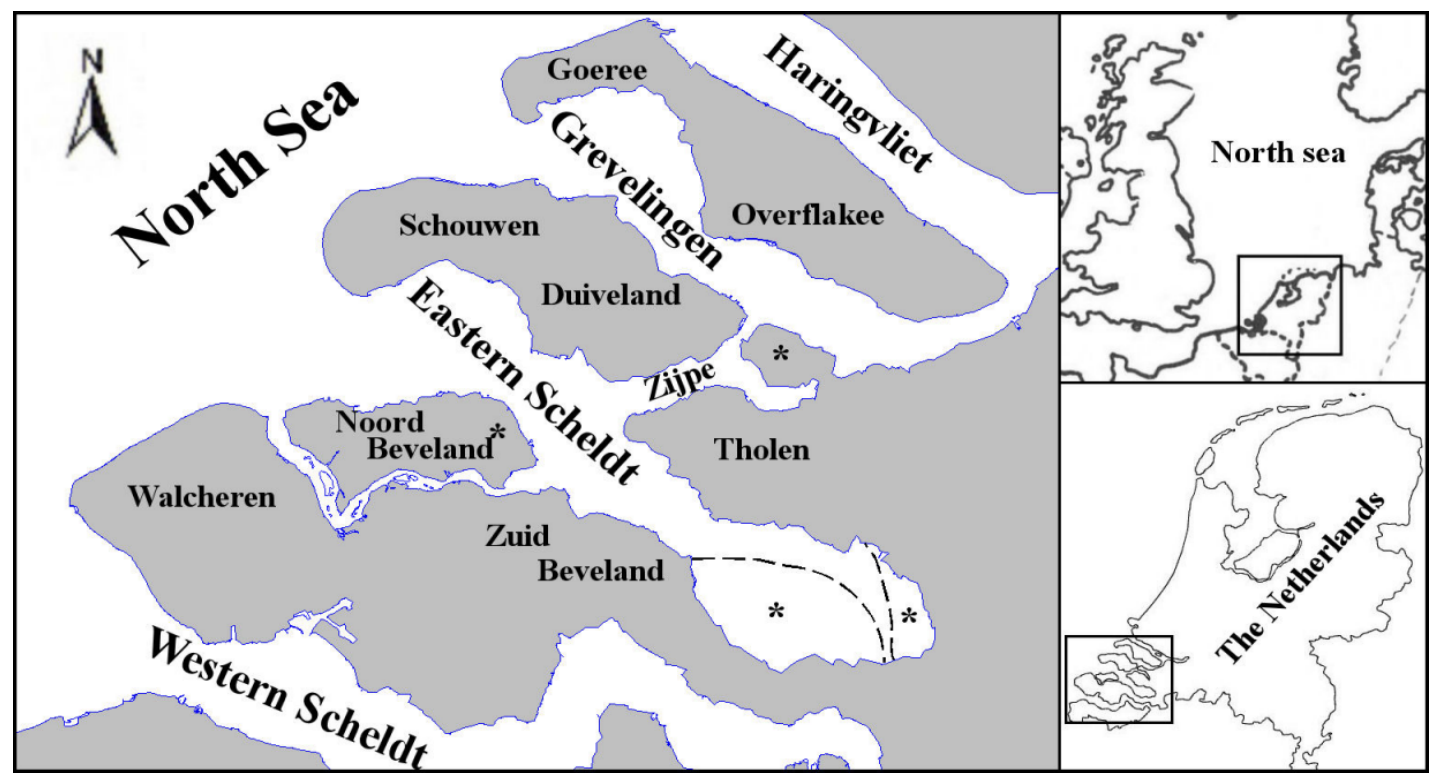

Figure 1: The situation of the Dutch Delta in 1950. The areas marked with an asterisk were inundated in the storm surge in 1530 A.D.

\footnotetext{
${ }^{1}$ Dept of Civil Eng., Delft University of Technology, Stevinweg 1, 2628 CN Delft, NL. m.eelkema@tudelft.nl

${ }^{2}$ Deltares, P.O. box 177, 2600 MH Delft, NL.wang@wldelft.nl
} 
The Eastern Scheldt basin and ebb-tidal delta have seen large changes in both shape and size over the last six centuries. Especially the configuration of the tidal basin has been dramatically changed by human influence as well as extreme events. These changes have not only had their impact on the system of flats and channels within the basin, but also on the shoals and channels of the outer delta.

This research is part of a larger ongoing study which aims to increase knowledge on the Dutch Delta coast and its interaction with the tidal basins connected to it. We hope that a better understanding of the historical evolution of this basin gives more insight into processes that dominate in the present-day situation. To investigate the evolution of the overall sediment balance and the large-scale configuration of the basin and the outer delta, historical observations and data regarding bathymetry, land reclamations and inundations are analyzed. This analysis is used to form hypotheses on possible links between different developments inside the basin and on the outer delta. These hypotheses are then tested using a twodimensional numerical flow model (Delft3D) of the Eastern Scheldt with a highly simplified geometry.

\section{Historical evolution of basin and outer delta}

\subsection{Land reclamations and inundations}

References to inhabitation of the islands around the Eastern Scheldt date back as far as Roman times. Starting from the end of the Middle Ages, the local inhabitants have made a continuous effort to reclaim the mudflats surrounding the islands (Figure 2). By 1500 A.D. most of the flats around Tholen and Duiveland had been reclaimed (Wilderom, 1964). During the $15^{\text {th }}$ century, the southern shore of Schouwen island began to erode under the attack of the newly-formed Hammen channel. This erosion continued until the end of the $16^{\text {th }}$ century (Beekman, 2007).

In 1530 and 1532 A.D. two large storm surges, the St. Felix flood and the All-Saints flood, inundated almost $200 \mathrm{~km}^{2}$. Most of this area, around $150 \mathrm{~km}^{2}$, was located in the eastern part of the basin. Along with this, Noord-Beveland and parts of Tholen became permanently flooded. Over the course of the next 100 years most inundated parts of Noord-Beveland and Tholen were reclaimed again. However, a large part of Zuid-Beveland $\left( \pm 95 \mathrm{~km}^{2}\right.$ ) remained inundated (Van den Berg, 1986).

During the $17^{\text {th }}$ century (the Dutch “Golden Age"), approximately $60 \mathrm{~km}^{2}$ was reclaimed around the Eastern Scheldt alone. However, most of this activity was merely reclaiming some of the land that was lost in the floods of 1530 and 1532 . In the $18^{\text {th }}$ and $19^{\text {th }}$ centuries the rate at which new polders were built was lower than before. However, the polders themselves became much larger. At the start of the $20^{\text {th }}$ century, the basin area stabilized and remained more or less constant until the second half of the century (Figure 3).

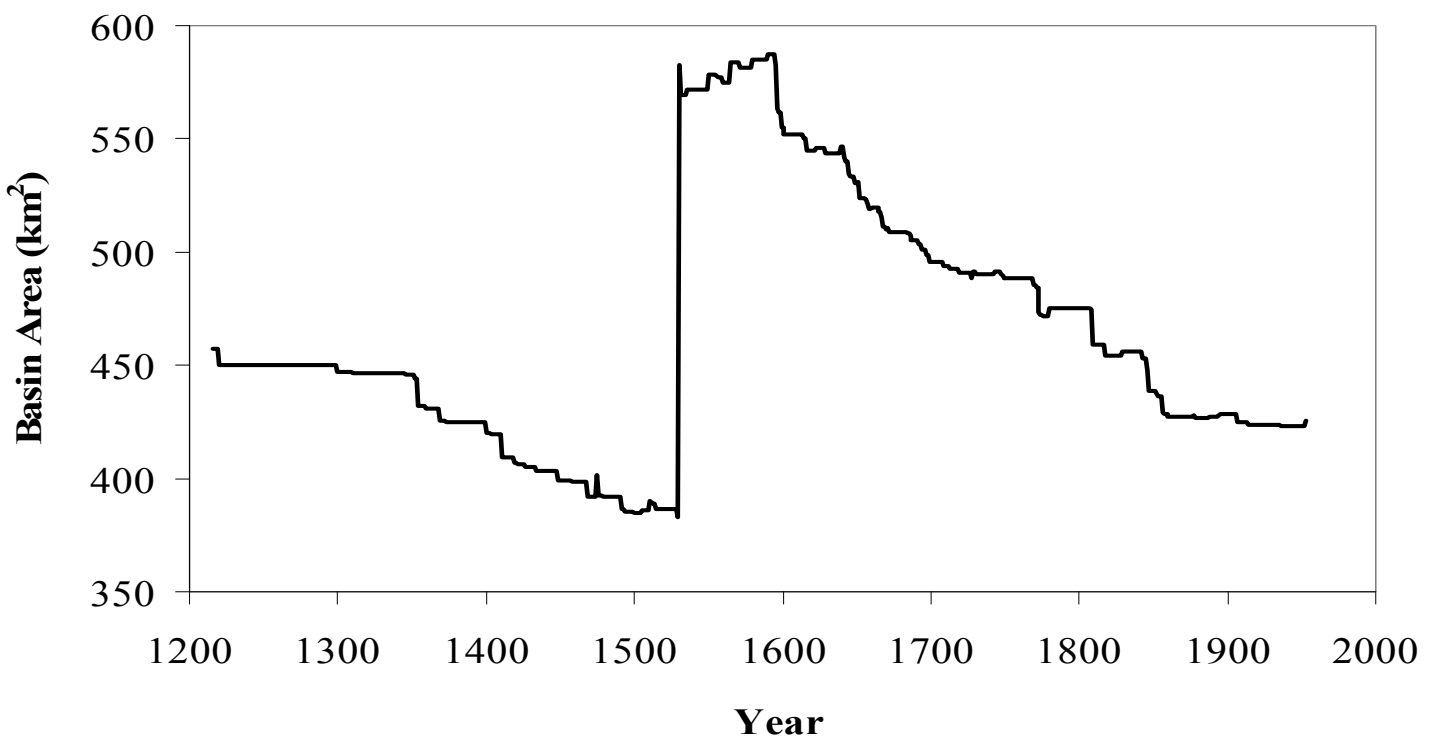

Figure 2: Development of wet basin area from middle-ages to 1950 A.D., based on Wilderom (1964). 


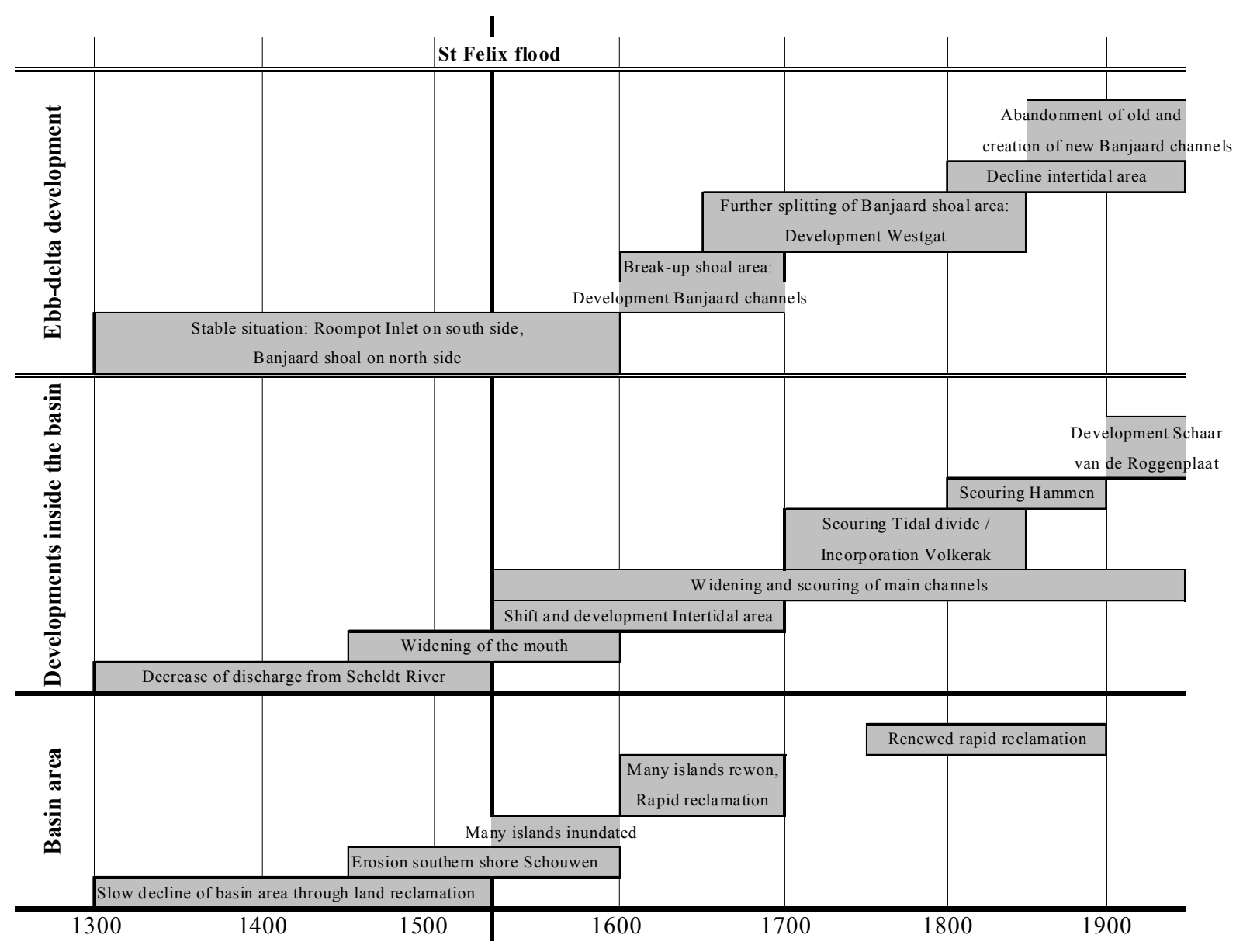

Figure 3: Chronology of basin and ebb-tidal delta development.

\subsection{Morphological changes within the basin}

At the beginning of the $15^{\text {th }}$ century, the Eastern Scheldt was a relatively shallow tidal basin. It was connected to neighboring basins through several shallow tidal watersheds. The connection to the Scheldt River in the eastern part of the basin silted up after the Western Scheldt became connected to the river. Eventually both connections between the Eastern and Western Scheldt were closed off with dams during the $19^{\text {th }}$ century.

After the cataclysmic floods in the years 1530 and 1532, the morphology began to change. The main channels in the middle part began to scour. This scouring continued without interuption until the completion of the storm-surge barrier in 1986. According to Haring (1978), approximately 265 million $\mathrm{m}^{3}$ of sediment were exported in the period between 1872 and 1950. In the rest of the Eastern Scheldt the increase in tidal volumes resulted in sedimentation on the flats and banks.

Before the $18^{\text {th }}$ century the connection between the Eastern Scheldt and the Grevelingen tidal basin to the north consisted of a broad shallow area known as the Zijpe. Historians have reported that in the $16^{\text {th }}$ century people could cross this area on foot at low tide. However, at the beginning of the $18^{\text {th }}$ century this tidal watershed began to scour, and by the end of the century the Zijpe had reached a depth of more than 20 meters. Due to this deepening, the tidal influence of the Eastern Scheldt began to reach into the landward end of the Grevelingen, known as the Volkerak. This process further increased the tidal prism, amplifying the scouring in the Zijpe and Eastern Scheldt channels. Van den Berg (1986) hypothesizes that the initial scouring was due to the deepening of the Eastern Scheldt channels, which increased the propagation speed of the tidal wave. According to Van den Berg (1986), the increase in phase difference across the Zijpe connection in favor of the Eastern Scheldt caused the tidal watershed to be pushed into the Grevelingen. 


\subsection{Ebb-tidal delta development}

Descriptions of the ebb-tidal delta of the Eastern Scheldt from before 1800 are rather sketchy. Until around 1600 A.D. the outer delta consisted of a large shoal, called the Banjaard, which stretched out from the beach of Schouwen, and was bound on the south by the Roompot channel. Apparently there were no channels running through this shoal. This situation changed at the end of the $16^{\text {th }}$ century, when the first charts appeared that displayed a channel separating the shoal from the beach of Schouwen. During the next century this single channel split up into at least two more channels cutting through the northern part of the Banjaard shoal. Around 1650 A.D. a fourth channel, called the Westgat, was reported to run through the centre on the Banjaard, cutting off a new shoal called the Noordland. All these new channels were probably fed by the ebb current coming from the Hammen channel, which no longer flowed straight into the Roompot. During all this time the Roompot and Hammen channels deepened continuously (Beekman, 2007).

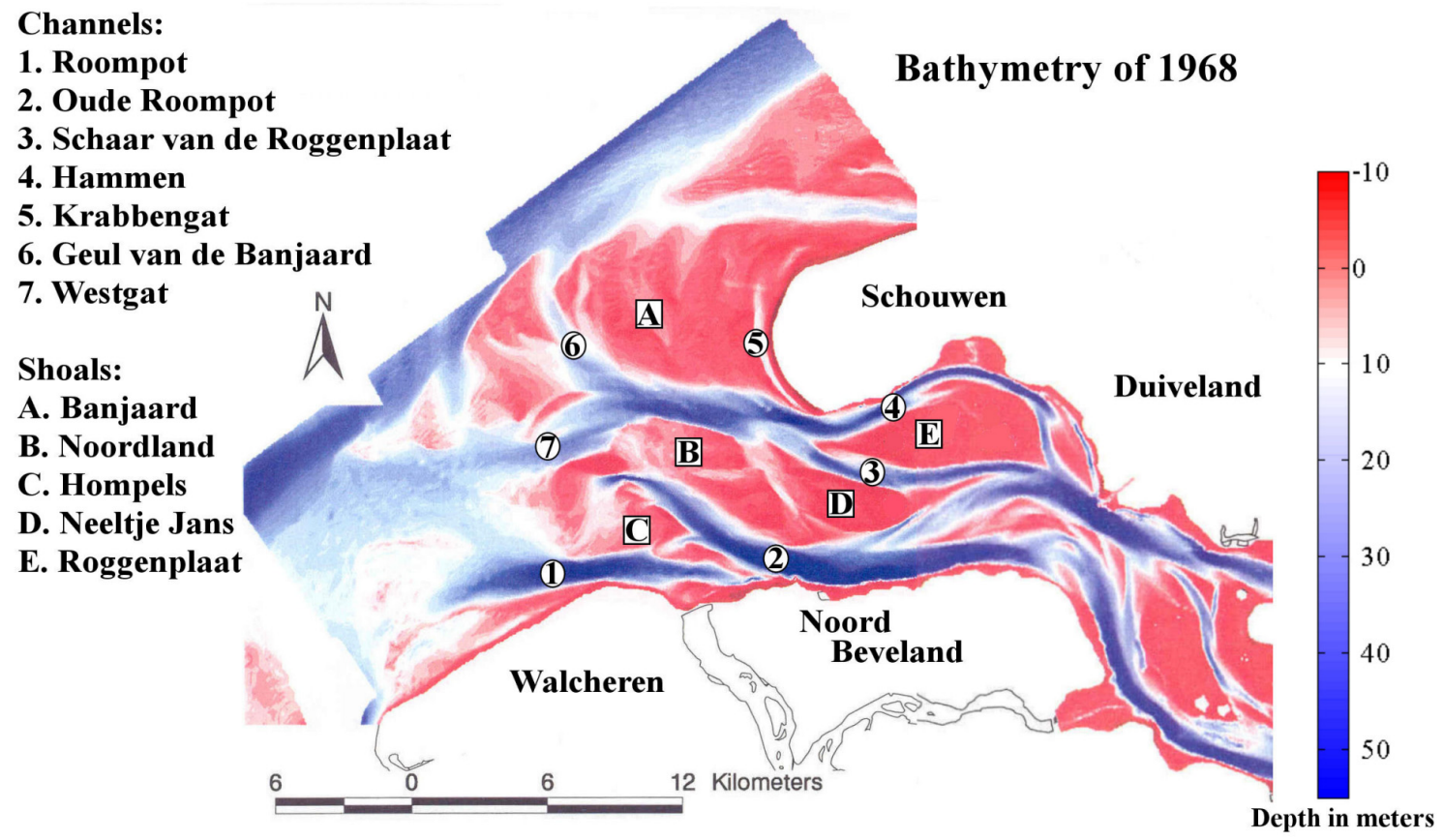

Figure 4: The ebb-tidal delta of the Eastern Scheldt in 1968.

The system of channels intersecting the Banjaard seems to have remained relatively stable for almost two centuries. At the end of the $19^{\text {th }}$ century, this configuration started to shift again (Figures 4 and 5): the Westgat straightened and widened, nearly all the intertidal area on the Banjaard and Noordland shoals disappeared, and one of the smaller channels through the Banjaard became abandoned. However, around 1930 A.D. a new ebb channel started cutting through the distal part of the shoal.

Overall, the development of the Eastern Scheldt outer delta from the $16^{\text {th }}$ century onward is characterized by a shift from an updrift ${ }^{3}$-oriented system with a single main channel to a more centrally oriented system. A cause for this shift could be the increase in intertidal area in the back of the basin after the floodings in 1530 A.D. This could have caused an increase in the phase difference between the horizontal tide in the inlet and the horizontal tide flowing alongshore, pushing the main channels downdrift (Sha \& Van den Berg, 1993). The increase in tidal prism probably also amplified the creation and deepening of new channels.

\footnotetext{
${ }^{3}$ Updrift relative to the direction of propagation of the alongshore tidal wave, which for the Netherlands is from southwest to northeast.
} 

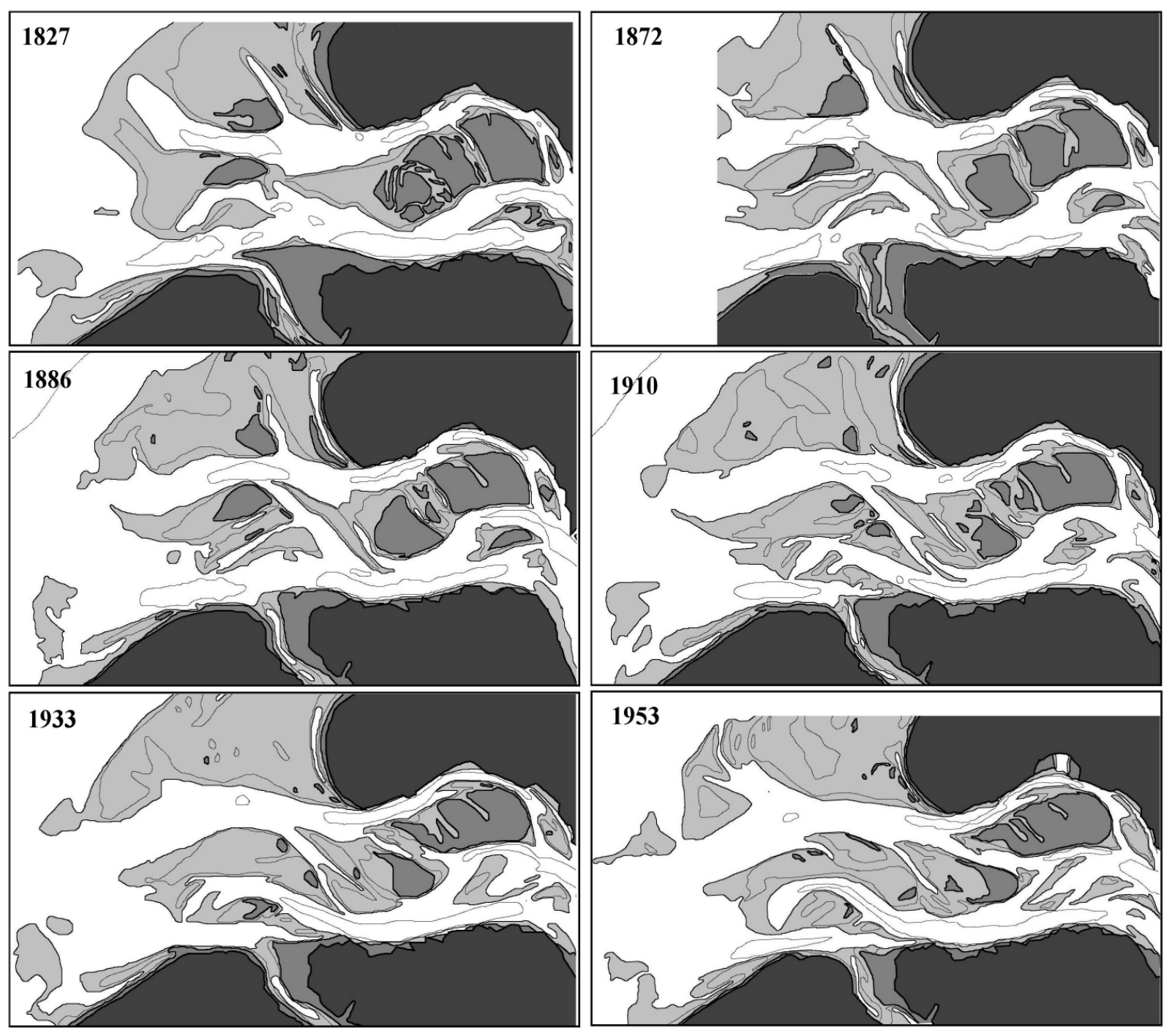

Figure 5: Development of the ebb-tidal delta from 1827 to 1953, after Haring (1978).

\section{Method and model}

\subsection{Reconstructing basin geometries}

To assess the effect of different basin geometries on the tidal hydrodynamics, six schematized basin geometries were reconstructed for five different periods in the basin's history. These reconstructions were then implemented in a depth-averaged Delft3D-model in order to calculate horizontal tides, tidal volumes, propagation speeds and tidal deformation. It was not our goal to reproduce historical tides exactly; we were merely interested in the differences in tidal volumes and propagation speed between different basin geometries. Furthermore, there is hardly any information available on the tide inside the Eastern Scheldt before the $19^{\text {th }}$ century. Therefore, the water levels and discharges in the model in this study are not calibrated to known values in any way.

All geometries consisted of two parallel rectangular basins with a $10 \mathrm{~km}$ long and $2 \mathrm{~km}$ wide connection in the middle. The northern basin was modeled to be analogous to the Grevelingen basin. In the same way the southern basin was modeled after the Eastern Scheldt. The total size of the basins $\left(\mathrm{A}_{\mathrm{b}}\right)$ was deduced from records on land reclamations and inundations (Figure 2). For the pre-1530 flood situation both basins (north and south) were approximately $50 \mathrm{~km}$ long and $7 \mathrm{~km}$ wide and had the same ratio between flat area and total area $\left(A_{f} / A_{b}=0.4\right.$ according to Eysink, 1991). The flats on both sides of the 
central channels have a linear slope. The equilibrium average height $h_{f}$ of the flats was determined according to the following empirical relation (Eysink, 1990):

$$
h_{f}=\left(0.41-0.24 \bar{\ni} 10^{-9} \bar{\ni} A_{b}\right) \overline{7} 2 a
$$

where $2 \mathrm{a}$ is the local tidal range. At the landward end of the basin the depth of the main channel below mean sea level was taken equal to the local low water level, and increased linearly to a pre-determined depth at the mouth. For the pre-1530 situation there are very few reliable reports on the depth across the mouth. Most sources speak of a depth between 10 and 15 meters (Beekman, 2007). In this study a depth of 14 meters was chosen to start with for both basins (Case 1).

The large-scale inundations of 1530 were modeled in Case 2 by adding $190 \mathrm{~km}^{2}$ of intertidal area to the banks of the southern basin $\left(140 \mathrm{~km}^{2}\right.$ in the landward part, $50 \mathrm{~km}^{2}$ in the mouth area). The height of the flats and the depth of the channels were left unaltered in order to make this second geometry resemble an instantaneous inundation. In the subsequent cases (Cases 3 through 6) the large-scale land reclamations were modeled by removing intertidal area from the banks of the southern basin (Table 1). The northern basin was kept unaltered for all cases. The depth of the connection channel between the northern and southern basin was kept at $2.5 \mathrm{~m}$ below mean sea level for all cases except for Case 6 . In this last case, the depth of the connection channel was increased to $10 \mathrm{~m}$.

Table 1: Depths and dimensions in different cases.

\begin{tabular}{|l|c|c|c|c|c|c|}
\hline & Case 1 & Case 2 & Case 3 & Case 4 & Case 5 & Case 6 \\
\hline \hline Depth mouth (x=L) southern basin $(\mathrm{m})$ & 14 & 14 & 14 & 17 & 17 & 20 \\
Depth middle (x=1/2L) southern basin (m) & 7.5 & 7.5 & 11 & 11 & 11 & 13 \\
Width main channel southern basin (m) & 4200 & 4200 & 4200 & 4200 & 4200 & 4200 \\
Surface area southern basin $\left(\mathrm{km}^{2}\right)$ & 350 & 540 & 490 & 490 & 425 & 425 \\
\hline Depth mouth (x=L) northern basin (m) & 14 & 14 & 14 & 14 & 14 & 14 \\
Depth middle (x=1/2L) northern basin (m) & 7.5 & 7.5 & 7.5 & 7.5 & 7.5 & 7.5 \\
Width main channel northern basin (m) & 4200 & 4200 & 4200 & 4200 & 4200 & 4200 \\
Surface area northern basin $\left(\mathrm{km}^{2}\right)$ & 350 & 350 & 350 & 350 & 350 & 350 \\
\hline Depth connection channel $(\mathrm{m})$ & 2.5 & 2.5 & 2.5 & 2.5 & 2.5 & 10 \\
\hline
\end{tabular}

\subsection{Boundary conditions}

The boundary conditions for both basins were prescribed as water levels. Both basins were forced by a cyclic tide with a period of 12.5 hours. This tide consisted of a semi-diurnal component plus its fourth- and sixth-diurnal overtides. The amplitudes and phases for all these components were deduced for both inlets from present day tidal measurements taken roughly $10 \mathrm{~km}$ seaward of the Grevelingen and Eastern Scheldt inlets (Table 2). This implies that the tides outside both basins have not changed much over the centuries. For all cases a uniform Manning-roughness coefficient of 0.028 was used.

Table 2: Water level boundary conditions

\begin{tabular}{|c|cc|cc|c|c|}
\hline \multirow{2}{*}{ Inlet } & \multicolumn{2}{|c|}{ Semidiurnal component } & \multicolumn{2}{c|}{ Fourth-diurnal component } & \multicolumn{2}{c|}{ Sixth-diurnal component } \\
\cline { 2 - 7 } & Amplitude $(\mathrm{m})$ & Phase (degrees) & Amplitude $(\mathrm{m})$ & Phase (degrees) & Amplitude (m) & Phase (degrees) \\
\hline Northern inlet & 1.08 & 270 & 0.15 & 181 & 0.07 & 1 \\
Southern inlet & 1.31 & 263 & 0.13 & 172 & 0.08 & 345 \\
\hline
\end{tabular}


Coastal Dynamics 2009

Paper No. 85

\section{Results}

\subsection{Development of tidal volumes}

The effect of the instantaneous enlargement of the intertidal area (Case 2) was that the tidal volumes at the southern mouth increase, but only by less than 2 percent (Table 3 ). This minor increase relative to the size of the inundation may seem counter-intuitive but was an effect of the decrease in tidal range, which counteracted the effect of the increase in storage area.

Table 3: Calculated tidal volumes, currents and ebb and flood durations.

\begin{tabular}{|l|c|c|c|c|c|c|}
\hline & Case 1 & Case 2 & Case 3 & Case 4 & Case 5 & Case 6 \\
\hline \hline Depth southern mouth $(\mathrm{x}=\mathrm{L})(\mathrm{m})$ & 14 & 14 & 14 & 17 & 17 & 20 \\
Depth southern middle $(\mathrm{x}=1 / 2 \mathrm{~L})(\mathrm{m})$ & 7.5 & 7.5 & 11 & 11 & 11 & 13 \\
Depth connection channel $(\mathrm{m})$ & 2.5 & 2.5 & 2.5 & 2.5 & 2.5 & 10 \\
Southern basin area $\left(\mathrm{km}^{2}\right)$ & 350 & 538 & 490 & 490 & 426 & 426 \\
\hline Average tidal volume northern mouth $\left(* 10^{6} \mathrm{~m}^{3}\right)$ & 640 & 635 & 638 & 637 & 638 & 645 \\
Average tidal volume southern mouth $\left(* 10^{6} \mathrm{~m}^{3}\right)$ & 738 & 750 & 881 & 917 & 914 & 1060 \\
Average tidal volume connection channel $\left(* 10^{6} \mathrm{~m}^{3}\right)$ & 23.7 & 3.3 & 19.0 & 24.1 & 29.0 & 132 \\
Residual flow from south to north $\left(* 10^{6} \mathrm{~m}^{3}\right)$ & 14.5 & 1.7 & 12.1 & 15.1 & 17.7 & 30.0 \\
\hline Flood period (min) & 376 & 338 & 376 & 390 & 396 & 406 \\
Ebb period (min) & 374 & 412 & 374 & 360 & 354 & 344 \\
Max flood current at southern inlet $(\mathrm{m} / \mathrm{s})$ & 0.94 & 1.04 & 1.07 & 0.93 & 0.89 & 0.87 \\
Max ebb current at southern inlet $(\mathrm{m} / \mathrm{s})$ & 0.95 & 0.93 & 1.16 & 1.03 & 1.01 & 0.97 \\
Flood/ebb period & 1.01 & 0.82 & 1.01 & 1.08 & 1.12 & 1.18 \\
Max flood current/Max ebb current & 0.99 & 1.12 & 0.92 & 0.91 & 0.88 & 0.90 \\
\hline
\end{tabular}

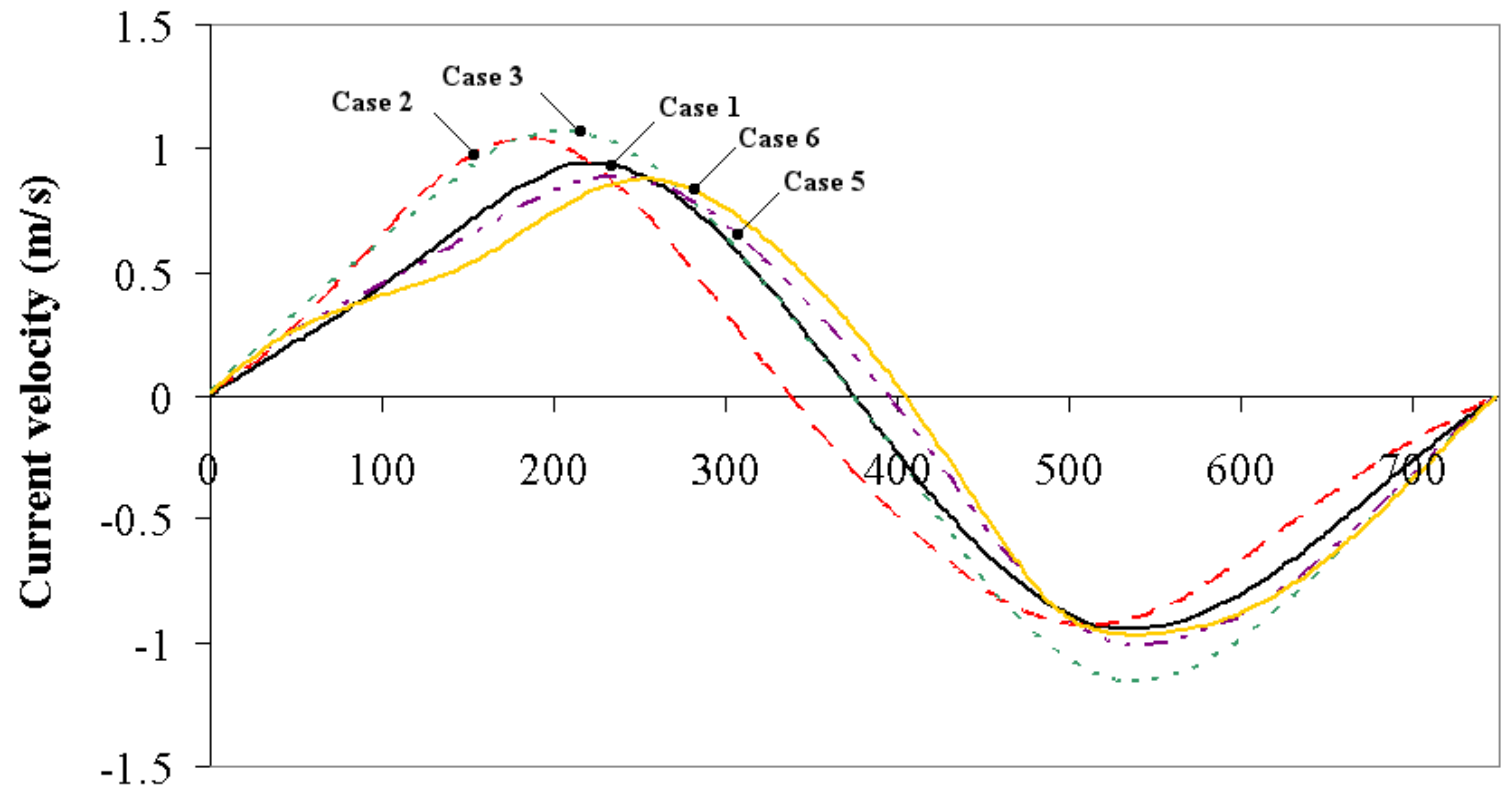

Time (min)

Figure 6: Current velocity curves across the southern inlet over one tidal cycle. Case 4 has been omitted for clarity reasons. 
Although at the mouth the tidal volumes stayed more or less the same between Cases 1 and 2, more inland the changes were much larger. At the location of the connection channel the tidal volume increased by 11 percent. This means that while the depth at the mouth might not change much, the middle part of the basin should begin to scour directly after the inundation. The results of Case 3 show that once the middle part of the basin was deepened, the mouth saw a large increase in tidal volume (17 percent increase). This increase led to more scour along the basin, which again led to more tidal volume. This is seen in Cases 4 and 5. The results from these two models also show that the decrease in basin area between these two cases takes away some of the tidal prism. Nevertheless, this decrease is not enough to counter the effect that the scouring has on the tidal range.

The southern basin in Case 1 has a hypsometry with a relative depth and an intertidal storage volume such that, according to Friedrichs \& Aubrey (1988), the basin should only have a very slight ebb dominance. The ebb and flood durations computed for Case 1 seem to validate this (Table 3 and Figure 6). With this hypsometry the ratio between the propagation speeds of the high and low water phases is almost 1, which means that high and low water propagate at almost the same speed. In Case 2, the duration of the flood period decreased sharply in response to the inundation all along the southern basin (Figure 6). This seems counter-intuitive, since various other studies have shown that an increase in intertidal area leads to an increase in flood duration (e.g. Friedrichs \& Aubrey, 1988; Van der Spek, 1997; Dronkers, 1998). According to the new hypsometry, the propagation speed of low water should have increased relative to high water. However, the decrease in flood duration in the model indicates a high water phase which is propagating faster than in Case 1.

The same kind of inconsistency with the prevailing theory on the relation between flood dominance and hypsometry was seen in Cases 4 and 5. The configuration of Case 5 was the same as Case 4, only with decreased intertidal area (simulating land reclamation). A decrease in intertidal area should have decreased the flood duration. However, in Case 5 the opposite occurred.

The probable cause for the decrease in flood duration seen in Case 2 is the way in which the depth of the central channel is implemented. In Case 1 the depth of this main channel at the landward end of the basin is set equal to the local low water level. However, this would mean that at this point the low water phase has no velocity since the water depth is zero. This causes the ratio between the propagation speeds of the high and low water phases to become very large locally.

\subsection{Location of the tidal divide}

For this study the tidal divide is defined as the location within the connection channel where there is a minimum in tide-averaged flow magnitudes, and also where the flow direction reverses. In the situations before and shortly after the increase in basin area (Cases 1 and 2) the tide-averaged flow velocities showed a distinct minimum in the middle of the connection channel halfway between both basins (Figures 7 and 8). When the main channel in the southern basin was deepened (Cases 3, 4, and 5), the location of the divide started to move north, although only by 500 meters at the most. Only after the connection channel itself was deepened from 2.5 to $10 \mathrm{~m}$ in Case 6 did the tidal divide move out of the connection completely. In Figure 7 this disappearance of the divide is also observed by the change of orientation of the jet coming out of the connection on the northern side. The location of the tidal divide did not seem to be very sensitive to the deepening of the southern basin. This is probably because not only the surface elevation phase difference over the connection increases, but also the amplitude ratio. If only the amplitude increases at the southern side while the phase stays the same, the location of the divide should actually shift south (Wang, 2009). This means that the decrease in phase at the southern side of the connection was mostly counteracted by the increase in the amplitude of the surface elevation.

The tidal volumes and the residual flow through the connection initially decreased dramatically in response to the inundations in the southern basin (Table 3). However, the scouring of the Eastern Scheldt caused these values to recover quickly. Case 4 already produced flows across the connection which were larger than the initial situation in Case 1, which means that from this point onward the connection channel was likely to scour. It is also noteworthy that a decrease in intertidal area in the southern basin caused these volumes to increase even more. This means that the scouring of the connection channel between the Grevelingen and Eastern Scheldt basin was not primarily an effect of the decrease in phase and the increase in amplitudes at the southern side. Instead, it was more an effect of the increase in tidal volumes through 
the connection channel, which was further amplified by the reclamation of intertidal area. For the Eastern Scheldt, the location of the tidal divide is much more sensitive to the depth than the boundary conditions. Therefore, the scouring is likely to have caused the disappearance of the divide.

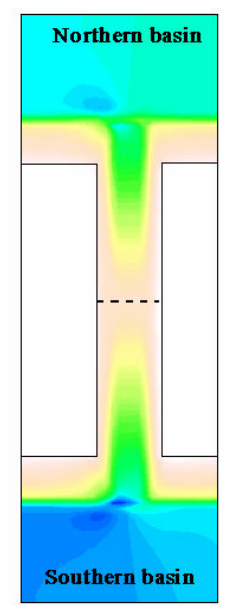

Case 1

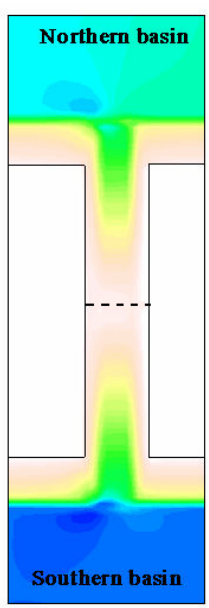

Case 2

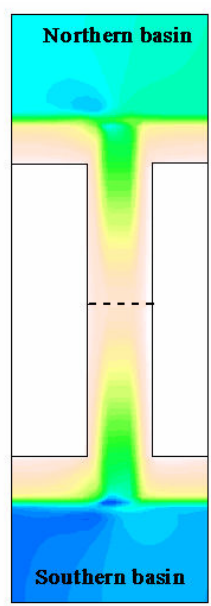

Case 3

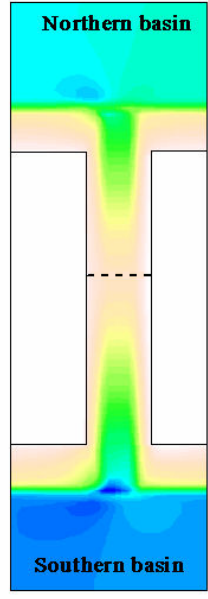

Case 4

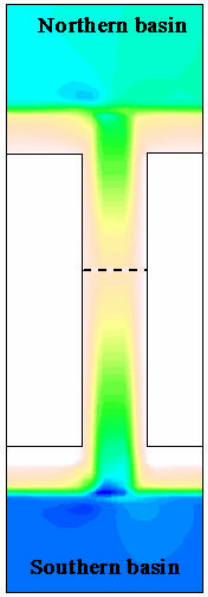

Case 5

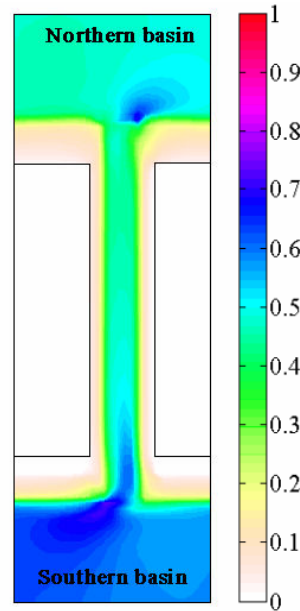

Case 6

Figure 7: Tide-averaged velocity magnitudes along connection channel (units in $\mathrm{m} / \mathrm{s}$ ). The dotted line indicates the location of the minimum in average flow velocities.

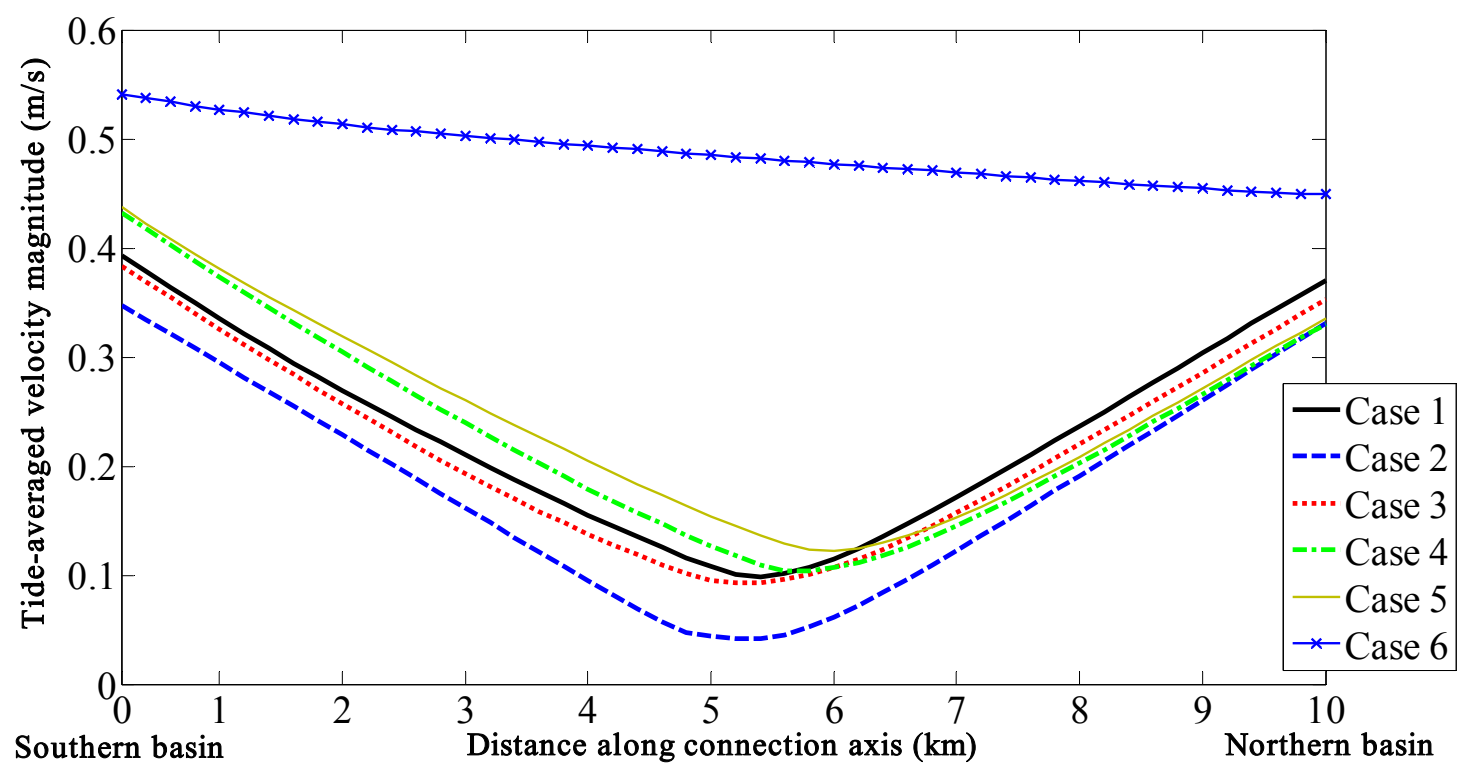

Figure 8: Tide-averaged velocity magnitudes along connection channel axis for all cases.

\subsection{Tidal currents in the inlet}

According to a detailed Delft3D-model of the modern-day situation, the alongshore current at the location of the Eastern Scheldt is almost in phase with the vertical tide in the inlet. Therefore, a shift in phase between horizontal and vertical tide in the inlet would also mean a shift in phase between horizontal alongshore and cross-shore tides. If the theory of Sha \& van den Berg (1993) applied in the situation of the Eastern Scheldt, the shift on the ebb-tidal delta should have corresponded with an increase in phase difference between the horizontal tide in the inlet and the horizontal alongshore tide. However, the modeled geometries for the periods directly after the floods produced a decrease rather than an increase in phase 
difference (Figure 9). Overall, the shifts in phase were not very large, and it is therefore unlikely that this is the cause for the shift in channel configuration across the ebb-tidal delta.

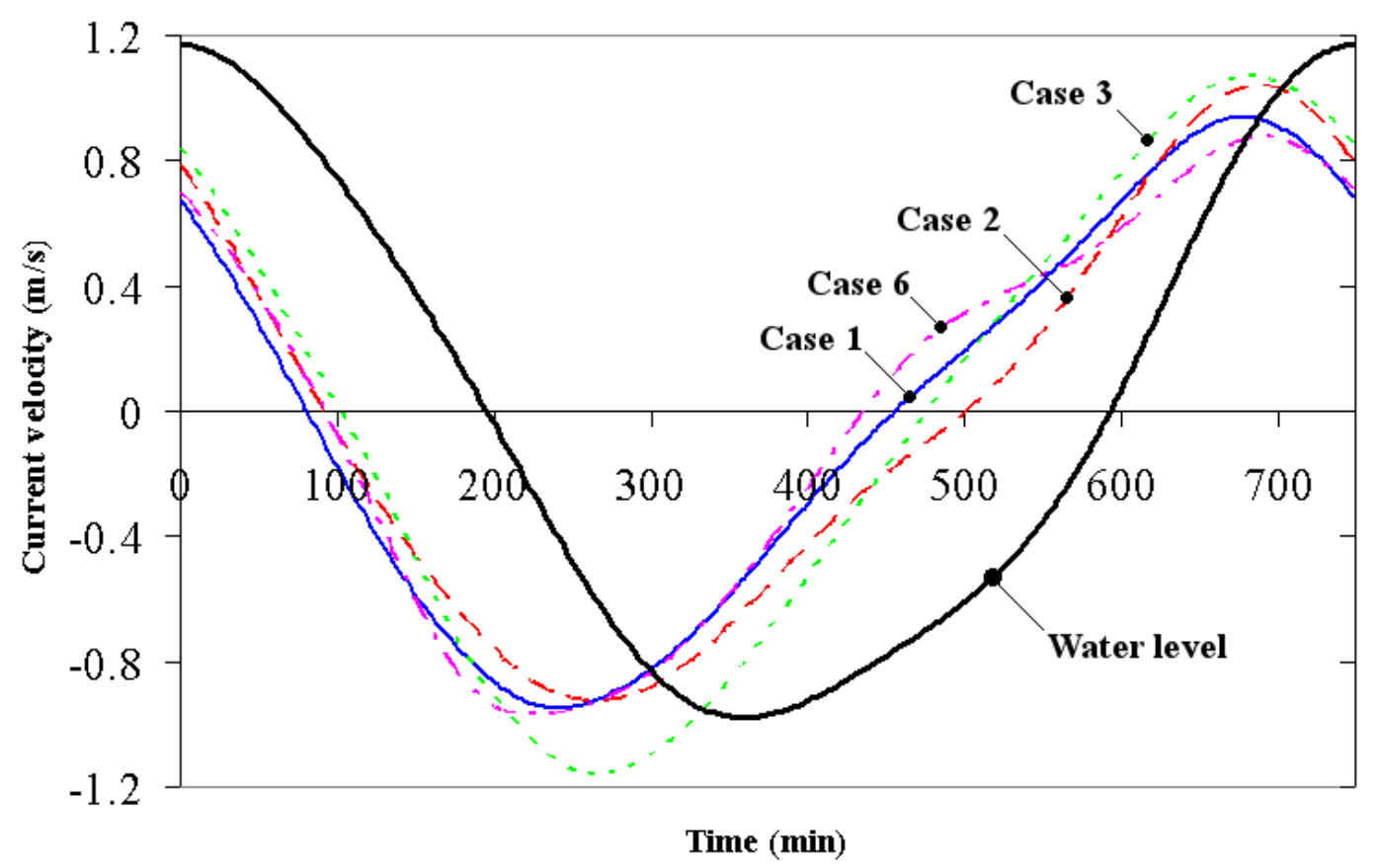

Figure 9: Calculated current velocities relative to the water level at the southern inlet. Cases 4 and 5 have been omitted for clarity reasons, but fall within the envelope created by Cases 3 and 6 .

It is possible that the creation and abandonment of the channels across the Banjaard shoal were merely the effect of the general increase in tidal prism through the inlet. As the ebb-tidal delta growed in response to this increase, the channels became not only deeper but also longer. At some point they became too long, and a new channel will have formed which was more hydraulically efficient. This process has also been observed during the construction of the dams in the back end of the basin in the 1960s and 1970s. These dams, which were part of the so-called Deltaplan, also caused an increase in tidal prism, and in response to this, the Oude Roompot channel straightened and became directly connected to the Westgat. A similar process might have created most other channels on the ebb-tidal delta.

\section{Conclusions}

Both the historical observations and the modeled cases presented in this paper support the theory of a basin evolution dominated by an exporting trend, with continuously increasing tidal prism and continuously deepening channels. This trend has been set in motion by the inundations in the $16^{\text {th }}$ century, and the land reclamations since then have not been able to decrease the tidal prism and probably only amplified the exporting trend. Even if the peculiar shortening of the flood period after the inundations observed in the model occurred in reality, it would not have influenced the evolution on the longer time scale. The main channels will still scour, and the tidal asymmetry seems to be much more sensitive to the depth of the channels than the amount of intertidal area. As a result of this scouring, the tidal divide between the Eastern Scheldt and the Grevelingen has disappeared, but only after the residual flow across this tidal watershed had increased, and the connection channel itself had scoured to greater depth.

The evolution of the ebb-tidal delta of the Eastern Scheldt between the $16^{\text {th }}$ and $20^{\text {th }}$ century was mostly governed by the continuous increase in tidal prism. This increase has led to not only a general increase of the sediment volume of the outer delta, but also to the development of the various channels running through this area. The orientation of these channels does not seem to be influenced much by the 
developments within the basin.

The phenomenon of increasing flood dominance with increasing intertidal area in this case is still not well-understood. Besides from this, the model described in this paper does not describe sediment transport in any direct way. Therefore, it would be worthwhile to study the historical evolution of the Eastern Scheldt with a morphological model.

\section{Acknowledgements}

This study is part of a larger case study into the morphodynamics of the Dutch Delta coast and the interaction with its tidal basins. Funding was provided by both the Dr. Ir. Cornelis Lely Foundation and the Ecoshape: Building with Nature program.

\section{References}

Beekman, F., 2007. De kop van Schouwen onder het zand: Duizend jaar duinvorming en duingebruik op een zeeuws eiland. Uitgeverij Matrijs.

Dronkers, J., 1998. Morphodynamics of the Dutch Delta. Proceedings of Physics of Estuaries and Coastal Seas, Dronkers, J., Scheffers, M.B.A.M. (Eds.), Balkema, Rotterdam.

Eysink, W.D., 1990. Morphological response of tidal basins to changes. Proc. $22^{\text {nd }}$ International Conference on Coastal Engineering, Delft, 1948-1961.

Eysink, W.D., 1991. Impact of sea level rise on the morphology of the Wadden sea in the scope of its ecological function, phase 1. Delft Hydraulics report H1300, Delft, The Netherlands.

Friedrichs, C. T. and Aubrey, D.G., 1988. Non-linear tidal distortion in shallow well-mixed estuaries: a synthesis. Estuarine, costal and shelf science, 27, 521-545.

Haring, J., 1978. De geschiedenis van de ontwikkeling van de waterbeweging en van het profiel van de getijdewateren en zeegaten van het zuidelijk deltabekken. Rijkswaterstaat, The Hague.

Sha, L. P. and Van den Berg, J.H., 1993. Variation in ebb-tidal delta geometry along the coast of the Netherlands and the German Bight. Journal of Coastal Research, 9(3), 730-746.

Van den Berg, J. H., 1986. Aspects of sediment- and morphodynamics of subtidal deposits of the Oosterschelde (the Netherlands). Rijkswaterstaat, no. 43/1986, The Hague.

Van der Spek, A. J. F., 1997. Tidal asymmetry and long-term evolution of Holocene tidal basins in the Netherlands: simulation of paleo-tides in the Schelde estuary. Marine Geology, 141, 71-90.

Wang, Z.B., 2009. Long-term development of the Dutch coastal systems. Preliminary report, Deltares.

Wilderom, M.H., 1964. Tussen afsluitdijken en deltadijken II: Noord-Zeeland. Littooy \& Olthoff, Middelburg. 